Taxonomy and systematics

\title{
Advances in the phylogeny of Helvella (Fungi: Ascomycota), inferred from nuclear ribosomal LSU sequences and morphological data
}

\author{
Avances en la filogenia de Helvella (Fungi: Ascomycota), inferida de secuencias nucleares \\ ribosomales de la subunidad grande y datos morfológicos
}

\author{
Fidel Landeros ${ }^{\mathrm{a}}$, Teresa Iturriaga ${ }^{\mathrm{b}}$, Aarón Rodríguez $^{\mathrm{c}}$, Georgina Vargas-Amado $^{\mathrm{c}}$, \\ Laura Guzmán-Dávalos ${ }^{\mathrm{c}, *}$ \\ ${ }^{a}$ Facultad de Ciencias Naturales, Universidad Autónoma de Querétaro, Avenida de las Ciencias s/n, 76270 Santiago de Querétaro, Qro., Mexico

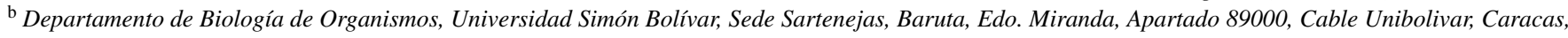 \\ Venezuela

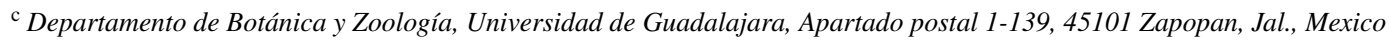

Received 6 February 2015; accepted 1 June 2015

Available online 10 November 2015

\begin{abstract}
Phylogenetic relationships in the genus Helvella were investigated using both LSU rDNA sequences and morphological features. The latter were coded and included in the analyses, resulting in better-supported clades. Helvella is monophyletic and Wynnella is its sister genus. Aporhynchous vs. pleurorhynchous asci are the synapomorphies for the 2 subgenera, Leucomelaenae and Helvella, which were confirmed as natural groups. Other recovered supported clades were section Leucomelaenae in the subgenus Leucomelaenae, and sections Elasticae, Helvella, and Lacunosae within the subgenus Helvella. Generic description, comments on taxonomically informative features, species complexes, and species that need typification are presented.

All Rights Reserved (C) 2015 Universidad Nacional Autónoma de México, Instituto de Biología. This is an open access item distributed under the Creative Commons CC License BY-NC-ND 4.0.

Keywords: Type specimens; Generic delimitation; Ecology; Distribution

\section{Resumen}

Se investigaron las relaciones filogenéticas en el género Helvella, utilizando secuencias de la subunidad grande del ADN ribosomal y características morfológicas; estas últimas se codificaron para incluirlas en el análisis, lo que resultó en clados con mejor soporte. Helvella es un grupo monofilético y Wynnella es su género hermano. Las ascas con base simple vs. las ascas con gancho en la base son sinapomorfias que ayudan en el reconocimiento de 2 subgéneros, Leucomelaenae y Helvella, que se confirman como grupos naturales. Otros clados con soporte son la sección Leucomelaenae en el subgénero Leucomelaenae y las secciones Elasticae, Helvella y Lacunosae dentro del subgénero Helvella. Se presentan la descripción genérica, comentarios de las características taxonómicamente importantes, complejos de especies y especies en las que es necesario nombrar tipos.

Derechos Reservados ( 2015 Universidad Nacional Autónoma de México, Instituto de Biología. Este es un artículo de acceso abierto distribuido bajo los términos de la Licencia Creative Commons CC BY-NC-ND 4.0.
\end{abstract}

Palabras clave: Especímenes tipo; Delimitación genérica; Ecología; Distribución

\section{Introduction}

* Corresponding author.

E-mail address: lguzman@cucba.udg.mx (L.Guzmán-Dávalos).

Peer Review under the responsibility of Universidad Nacional Autónoma de México.
The genus Helvella L. (Linnaeus, 1753) contains approximately 52 species (Kirk, Cannon, \& David, 2008). Its limits were established by Nannfeldt (1937) based on excipular tissue 

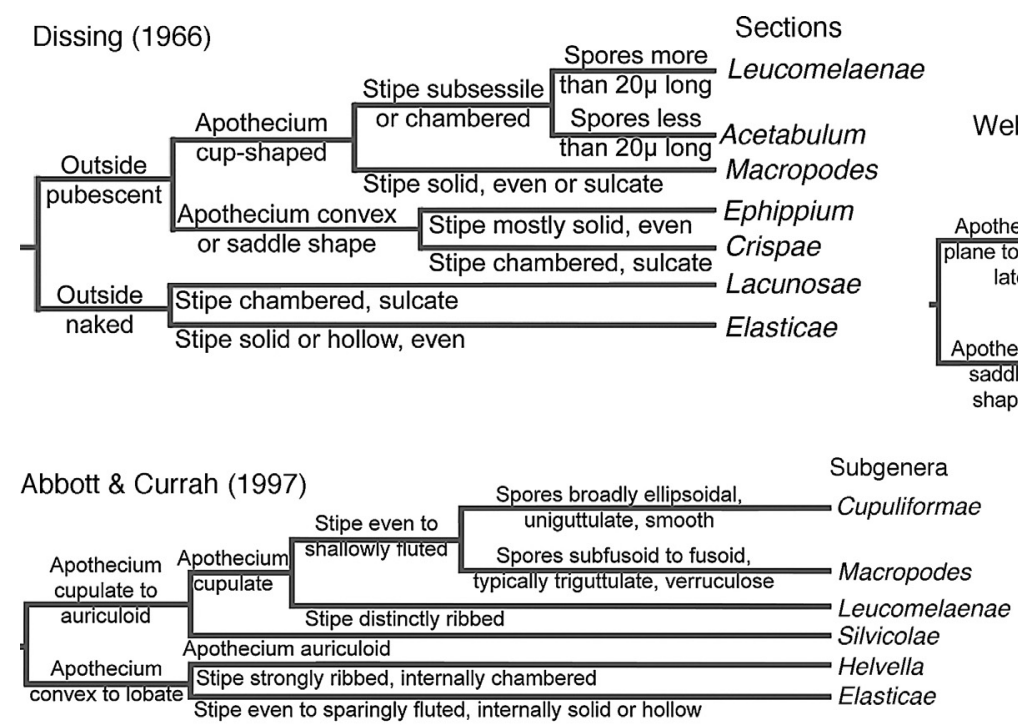

Figure 1. Traditional infrageneric classifications of Helvella. and ascospore characteristics. He described the excipulum as having 2 layers, one with intricate interwoven hyphae and the other with almost isodiametrical cells. Later, Korf (1952) named these types of tissues textura intricata, which constitutes the medullary excipulum, and textura angularis to prismatica for tissues in the ectal excipulum. Also, Nannfeldt (1937) described the ascospores of Helvella as having a large central guttula, sometimes with small apical guttulae, and tetra-nucleate (with 2 nuclei at each end).

Phylogenetic studies indicate that the family Helvellaceae is a monophyletic group (Hansen \& Pfister, 2006; Læssøe \& Hansen, 2007; O’Donnell, Cigelnik, Weber, \& Trappe, 1997) consisting of 5 genera: Balsamia Vittad., Barssia Gilkey, Helvella, Underwoodia Peck, and Wynnella Boud. In all these studies, few sequences of Helvella were included, and the phylogenetic position of Wynnella silvicola (Beck) Nannf., which had been regarded as $H$. silvicola (Beck) Harmaja by some authors (Abbott \& Currah, 1997; Häffner, 1987; Harmaja, 1974), was not established. In fact, Parslow and Spooner (2009) mentioned that the actual taxonomic position of Wynnella would be found only after a thorough study of Helvella spp., combining molecular and morphological characters. The genus Wynella is monotypic, macromorphologically characterized by a reddish brown earshaped apothecium, which distinguishes it from Helvella, with a cup-shaped to saddle shaped apothecium. Microscopically, both genera do not differ in any essential character (Dissing, 1966; Eckblad, 1968).

Several infrageneric classifications have been proposed based on morphological characters (Fig. 1). Dissing (1966) split the genus in 7 sections; Weber (1972) recognized Dissing's 7 sections, some having different limits, and added ascus development (aporhynchous vs. pleurorhynchous) as a diagnostic character. The most recent infrageneric classification of Helvella was proposed by Abbott and Currah (1997), accepting 6 subgenera, based on macro- and micromorphological features.

Because the sister group of Helvella and its infrageneric relationships are not known, this study aims to (1) investigate the position of Wynnella, and (2) improve our understanding of the phylogenetic relationships within Helvella using morphological data and DNA sequences of the nuclear ribosomal large subunit (nrLSU) region. For the first aim, all genera of Helvellaceae were included, as well as other genera of Discomycetes. For the second aim, representative taxa of all known sections were examined (including type specimens) from 12 countries in America, Africa, Asia, Europe, and Oceania.

\section{Materials and methods}

Eighteen type specimens and 91 additional ones from 16 herbaria: DAOM, ENCB, FCME, H, IBUG, K, MICH, NY, O, OSC, OULU, PRM, S, TAAM, UPS, and WTU, were studied. Herbaria abbreviations follow Thiers (2012). The material was studied according to the methodology described by Landeros, Iturriaga, and Guzmán-Dávalos (2012), that is to cut sections of the apothecia and stipes directly from the dry ascoma with a razor blade. Tissue sections were placed first in $96 \%$ ethyl alcohol and subsequently in water, Melzer's reagent, or cotton blue-lactophenol (Largent, Johnson, \& Watling, 1977). The terminology used here is that described by Landeros et al. (2012), except for the use of the dextrinoid term with Melzer's reagent, here abbreviated as Dx+, instead of hemiamyloid ( $\mathrm{rr}+$ ), which was incorrectly used by Landeros et al. (2012) because that term applies to the use of lugol, not Melzer's reagent (Baral, 1987).

\section{DNA extraction, amplification and sequencing}

The proteinase K protocol (Aljanabi \& Martínez, 1997) was used. The DNA pellet was diluted in 100-500 $\mu$ l of TE (Tris $10 \mathrm{mM}$ pH 7.4, EDTA $0.2 \mathrm{mM}$ ), kept at room temperature overnight, and stored at $-20^{\circ} \mathrm{C}$ until the DNA amplification step.

The polymerase chain reaction (PCR) was performed to amplify the D1 and D2 domains of the nrLSU. A Taq DNA polymerase Recombinant Kit (Invitrogen) was used. Primer pairs 


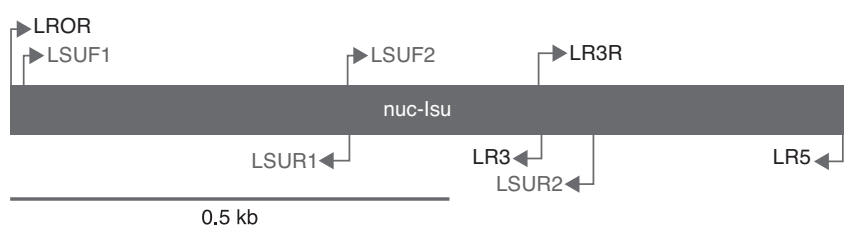

Figure 2. Location of the primers used in this work. Primers designed specifically for Helvella are shaded gray.

LROR-LR3 (White, Bruns, Lee, \& Taylor, 1990) were used to amplify the first $600 \mathrm{bp}$. Because the DNA of 25 ascomata appeared to be deteriorated, mainly in the type specimens, we designed 4 additional Helvella-specific internal primers using the Lasergene Primer Select Ver. 7.1.0 (44) (DNAStar, Inc.) software. These primers amplify segments of approximately $300 \mathrm{bp}$ and were designated as: LSUF1 (AGCGGAGGAAAGAAACCAACAG), LSUR1 (CTCTACTTGTGCGCTATCGGTCT), LSUF2 (AGACCGATAGCGCACAAGTAGAG), and LSUR2 (TCCCAACAGCTATGCTCCTACTC) (Fig. 2).

DNA amplification was performed in an Eppendorf Mastercycler Personal 5332 thermocycler using the protocol of White et al. (1990) with some modifications. The amplification program included a denaturation period of $5 \mathrm{~min}$ at $95^{\circ} \mathrm{C}$, followed by 35 cycles of denaturation at $95^{\circ} \mathrm{C}$ for $1 \mathrm{~min}$, annealing at $52-54^{\circ} \mathrm{C}$ for $90 \mathrm{~s}$, and extension at $72^{\circ} \mathrm{C}$ for $105 \mathrm{~s}$. A final extension cycle of $72^{\circ} \mathrm{C}$ for $10 \mathrm{~min}$ ended the process and the reaction was held at $4^{\circ} \mathrm{C}$. GFX PCR DNA columns and Gel Band Purification Kits (GE Healthcare) were used to purify PCR products, following the manufacturer's instructions.

The sequencing reaction was carried out with BigDye Terminator v3.1 (Applied Biosystems, Wellesley, MA). Sequencing products were purified using an AutoSeq G-50 Dye Terminator Removal Kit (GE Healthcare), following the instructions of the manufacturer. Sequences were visualized using an ABI-Prism 310 Genetic Analyzer (Applied Biosystems).

\section{Phylogenetic analysis}

Taxon sampling. Sequences of the nrLSU DNA were generated from 42 specimens (including 11 type specimens) of Helvella, representing 26 species, plus one sequence of Wynnella silvicola (Table 1). Furthermore, 42 additional sequences of Helvella were obtained from GenBank, plus another of $W$. silvicola, and 15 of the outgroup. The 92 sequences assembled for this study come from specimens of 12 countries.

DNA alignment. Sequences were edited using Chromas Pro Ver. 1.41 (Technelysium Pty, Ltd, Tewantin, Qld, Australia). Every sequence was then subjected to a BLAST search in GenBank and ambiguous sequences were removed. DNA alignments were checked by eye and manually corrected when necessary using MacClade 4.0 (Maddison \& Maddison, 2000).

Morphological data. A matrix of 15 morphological and chemical characters were used. Appendix I shows character coding and Appendix II the morphological and chemical matrix.

Phylogenetic inference. The first phylogenetic analysis was done to determine the position of the genus Wynnella and the second to establish the phylogeny within Helvella. In the first analysis, a matrix comprising species of Helvellaceae, Tuberaceae, Rhizinaceae, and Discinaceae with $101 \mathrm{LSU}$ sequences and $487 \mathrm{bp}$ was constructed; $459 \mathrm{bp}$ remained when ambiguous regions were excluded. To determine the phylogeny of Helvella, 68 specimens producing a matrix of $499 \mathrm{bp}$ and 15 morphological and chemical data was used. Phylogenetic analyses were conducted using maximum parsimony (MP), maximum likelihood (ML), and Bayesian inference. MP was executed in PAUP* $4.0 \mathrm{~b} 10$ (Altivec) (Swofford, 2002), with the following parameters: gaps as missing characters, heuristic searches with changes among character states having equal weights, 1,000 replicates, tree-bisection-reconnection (TBR) as the branch swapping algorithm, branches collapsed if maximum branch length was zero, and molecular data as the "DNA" option and morphological and chemical data as "mixed". MP bootstrap support (BS-MP) was obtained from 1,000 replicates (Felsenstein, 1985). RAxML 7.2.6 (Stamatakis, 2006), implemented in raxmlGUI 0.93 (Silvestro \& Michalak, 2010), was used for the ML search, consisting of 100 replicates to find the best ML tree using the GTRGAMMA model for molecular data and the GTR model for morphological and chemical data; bootstrap support (BS-ML) was calculated with 1,000 replicates using the same models. Bayesian analyses were conducted in MrBayes 3.1.2 (Ronquist \& Huelsenbeck, 2003). The best substitution model, GTR+G+I, was determined by Modeltest 3.7 (Posada \& Crandall, 1998). The parameters in the Bayesian search were set as GTR model, rates $=$ invgamma, ngen $=100,000,000$, nruns $=4$, samplefreq $=100$, and the first $50 \%$ of the samples were discarded. For morphological and chemical data, the program MrBayes was run with nst $=1$ (basic model) and rates $=$ gamma.

\section{Results}

The first analysis (Fig. 3) shows Wynnella silvicola as the sister group of Helvella (BML: 97, BMP: 88, PP: 100), i.e., our analysis supports the proposal of Dissing (1966), who considered it as a separate genus. Thus, W. silvicola was used as the outgroup in the second analysis.

The ML phylogram yielded 2 major clades (Fig. 4): (1) Helvella subgen. Leucomelaenae (BML: 55, BMP: 75, PP: -) formed by Acetabula calyx Sacc. (=H. leucomelaena), H. leucomelaena (Pers.) Nannf., and H. oblongispora Harmaja, and (2) Helvella subgen. Helvella (BML: 85, BMP: 73, PP: 99) formed by the remaining Helvella species. Within subgen. Helvella, 3 monophyletic groups were supported: (1) sect. Lacunosae (BML: 60, BMP: 67, PP: 100) [H. alpestris Boud. sensu Häffner (1987), H. dryophila Vellinga \& N.H. Nguyen, $H$. fusca Gillet, $H$. lacunosa Afzel., $H$. aff. sulcata, and $H$. vespertina N.H. Nguyen \& Vellinga], (2) sect. Helvella (BML: 80, BMP: 92, PP: 100) [H. crispa (Scop.) Fr. and H. maculata N.S. Weber], and (3) sect. Elasticae (BML: 60, BMP: 59, PP: 96) [H. albella Quél., H. compressa (Snyder) N.S. Weber, H. connivens Dissing \& M. Lange, H. elastica Bull., and $H$. stevensii Peck]. Unfortunately, several species affinities could not be elucidated. 
Table 1

Sequenced specimens of Helvella and outgroup.

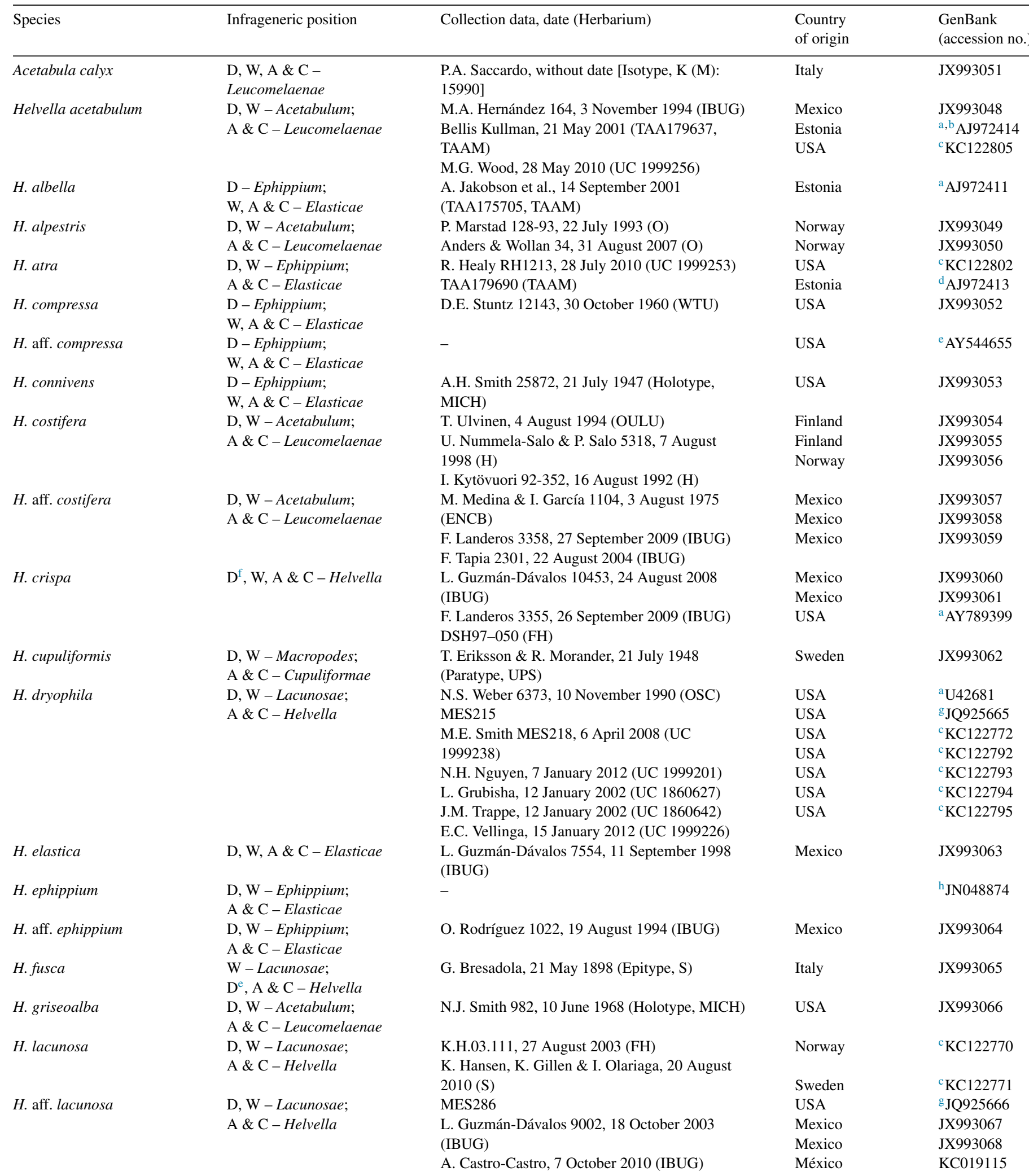

F. Padilla, 20 August 1985 (IBUG) 
Table 1 (Continued)

\begin{tabular}{|c|c|c|c|c|}
\hline Species & Infrageneric position & Collection data, date (Herbarium) & $\begin{array}{l}\text { Country } \\
\text { of origin }\end{array}$ & $\begin{array}{l}\text { GenBank } \\
\text { (accession no.) }\end{array}$ \\
\hline \multirow[t]{6}{*}{ H. leucomelaena } & $\mathrm{D}, \mathrm{W}, \mathrm{A} \& \mathrm{C}-$ & P. Billekens \& J. Legarde, 22 May $1982(\mathrm{H})$ & Netherlands & JX993069 \\
\hline & Leucomelaenae & $\begin{array}{l}\text { F.D. Calonge 15990, } 11 \text { May } 1980 \text { [K, ex herb. } \\
\text { MA-Fungi 15990] }\end{array}$ & Spain & JX993070 \\
\hline & & Beauglehole \& Fuhrer (Beaton 333), 23 July & Australia & JX993075 \\
\hline & & $1966(\mathrm{~K})$ & USA & ${ }^{\mathrm{i}} \mathrm{KC} 012682$ \\
\hline & & K. Hansen \& G. Lewis-Gentry, K.H.06.01 (FH) & USA & ${ }^{\mathrm{c}} \mathrm{KC} 122799$ \\
\hline & & D.J. Klein, 16-Mar-2012 (UC 1999257) & & \\
\hline \multirow[t]{2}{*}{ H. aff. leucomelaena } & $\mathrm{D}, \mathrm{W}, \mathrm{A} \& \mathrm{C}-$ & E.C. Vellinga, 18 March 2012 (UC 1999258) & USA & ${ }^{\mathrm{c}} \mathrm{KC} 122798$ \\
\hline & Leucomelaenae & & & \\
\hline \multirow[t]{5}{*}{ H. macropus } & $\mathrm{D}, \mathrm{W}, \mathrm{A} \& \mathrm{C}-$ & MES198 & USA & ${ }^{g}$ JQ925667 \\
\hline & Macropodes & O. Rodríguez 3409, 24 August 2008 (IBUG) & Mexico & JX993071 \\
\hline & & F. Landeros 3396a, 9 October 2010 (IBUG) & Mexico & JX993072 \\
\hline & & F. Landeros 3396c, 9 October 2010 (IBUG) & Mexico & JX993073 \\
\hline & & M.E. Smith MES198 & USA & ${ }^{\mathrm{c}} \mathrm{KC} 122774$ \\
\hline \multirow{4}{*}{ H. maculata } & $\mathrm{D}^{\mathrm{e}}, \mathrm{W}, \mathrm{A} \& \mathrm{C}-$ Helvella & N.J. Smith 2124, 5 October 1968 (Holotype, & USA & JX993074 \\
\hline & & $\mathrm{MICH})$ & USA & ${ }^{\mathrm{c}} \mathrm{KC} 122797$ \\
\hline & & E.C. Vellinga, 28 January 2012 (UC 1999255) & USA & ${ }^{\mathrm{c}} \mathrm{KC} 122800$ \\
\hline & & N.H. Nguyen, 10 December 2007 (UC 1999251) & & \\
\hline \multirow[t]{2}{*}{ H. oblongispora } & $\mathrm{D}, \mathrm{W}, \mathrm{A} \& \mathrm{C}-$ & M. Korhonen 5421, 22 August $1983(\mathrm{H})$ & Sweden & JX993076 \\
\hline & Leucomelaenae & U. Söderholm 2916, 17 June 1999 (H) & Austria & JX993077 \\
\hline H. pallidula & $\begin{array}{l}\text { D, W-Macropodes; } \\
\text { A \& C - Cupuliformae }\end{array}$ & N.J. Smith 397, 24 July 1967 (Holotype, MICH) & USA & JX993078 \\
\hline H. robusta & $\begin{array}{l}\mathrm{D}, \mathrm{W}-\text { Acetabulum; } \\
\text { A \& C - Leucomelaenae }\end{array}$ & $\begin{array}{l}\text { R.M. Danielson 459, } 30 \text { August } 1972 \text { (Holotype, } \\
\text { DAOM) }\end{array}$ & Canada & JX993079 \\
\hline \multirow[t]{3}{*}{ H. solitaria } & $\mathrm{D}, \mathrm{W}-$ Acetabulum & - & & jAM397273 \\
\hline & A \& C - Leucomelaenae & $\begin{array}{l}\text { Herrera de Duero 1294, } 31 \text { March } 2001 \text { (MA } \\
\text { Fungi 54822) }\end{array}$ & Spain & KP860988 \\
\hline & & $\begin{array}{l}\text { A. González, J.C. Campos et al., G.P. 1395, } 7 \\
\text { April } 2001 \text { (MA-Fungi 73836) }\end{array}$ & Spain & KP860989 \\
\hline H. stevensii & $\begin{array}{l}\mathrm{D}-\text { Ephippium; } \\
\mathrm{W}, \mathrm{A} \& \mathrm{C}-\text { Elasticae }\end{array}$ & Stevens, 23 June 1905 (NY) & USA & JX993080 \\
\hline H. subglabra & $\begin{array}{l}\mathrm{D}, \mathrm{W}-\text { Ephippium; } \\
\mathrm{A} \& \mathrm{C}-\text { Elasticae }\end{array}$ & $\begin{array}{l}\text { N.J. Smith 2145, } 13 \text { October } 1968 \text { (Holotype, } \\
\text { MICH) }\end{array}$ & USA & JX993081 \\
\hline \multirow[t]{3}{*}{ H. aff. sulcata } & $\mathrm{D}, \mathrm{W}$ - Lacunosae; & C.T. Rogerson, 29 July 1962 (NY) & USA Mexico & JX993082 \\
\hline & A \& $\mathrm{C}-$ Helvella & De Ávila 13B, without date (ENCB) & Mexico & JX993083 \\
\hline & & F. Landeros 1848, 7 August 2004 (IBUG) & & JX993084 \\
\hline H. ulvinenii & $\begin{array}{l}\mathrm{D}, \mathrm{W}-\text { Acetabulum; } \\
\text { A \& C - Leucomelaenae }\end{array}$ & H. Harmaja, 25 August 1979 (Holotype, H) & Finland & JX993085 \\
\hline \multirow[t]{16}{*}{ H. vespertina } & $\mathrm{D}, \mathrm{W}$ - Lacunosae; & E.C. Vellinga, 27 December 2011 (UC 1999195) & USA & ${ }^{\mathrm{c}} \mathrm{KC} 122775$ \\
\hline & $\mathrm{A} \& \mathrm{C}-$ Helvella & S. Branco, 7 January 2012 (UC 1999203) & USA & ${ }^{\mathrm{c}} \mathrm{KC} 122776$ \\
\hline & & BAMS, 11 October 2011 (UC 1999193) & USA & ${ }^{\mathrm{c}} \mathrm{KC} 122777$ \\
\hline & & BAMS, 11 October 2011 (UC 1999194) & USA & ${ }^{\mathrm{c}} \mathrm{KC} 122778$ \\
\hline & & N.H. Nguyen, 19 November 2011 (UC 1999206) & USA & ${ }^{\mathrm{c}} \mathrm{KC} 122780$ \\
\hline & & M. Brown, 29 October 2011 (UC 1861236) & USA & ${ }^{\mathrm{c}} \mathrm{KC} 122781$ \\
\hline & & E.C. Vellinga, 23 October 2011 (UC 1999197) & USA & ${ }^{\mathrm{c}} \mathrm{KC} 122782$ \\
\hline & & N.H. Nguyen, 19 November 2011 (UC 1999207) & USA & ${ }^{\mathrm{c}} \mathrm{KC} 122783$ \\
\hline & & N.H. Nguyen, 20 November 2011 (UC 1999212) & USA & ${ }^{\mathrm{c}} \mathrm{KC} 122784$ \\
\hline & & A. Ward, 22 November 2011 (UC 1999214) & USA & ${ }^{\mathrm{c}} \mathrm{KC} 122785$ \\
\hline & & N.H. Nguyen, 28 January 2012 (UC 1999215) & USA & ${ }^{\mathrm{c}} \mathrm{KC} 122786$ \\
\hline & & BAMS, 7 January 2012 (UC 1999202) & USA & ${ }^{\mathrm{c}} \mathrm{KC} 122787$ \\
\hline & & N.H. Nguyen, 19 November 201 (UC 1999205) & USA & ${ }^{\mathrm{c}} \mathrm{KC} 122788$ \\
\hline & & N.H. Nguyen, 20 November 2011 (UC 1999213) & USA & ${ }^{\mathrm{c}} \mathrm{KC} 122789$ \\
\hline & & N.H. Nguyen, 19 November 2011 (UC 1999209) & USA & ${ }^{\mathrm{c}} \mathrm{KC} 122790$ \\
\hline & & N.H. Nguyen, 20 November 2011 (UC 1999210) & USA & ${ }^{\mathrm{c}} \mathrm{KC} 122791$ \\
\hline Peziza subclavipes & $\begin{array}{l}\mathrm{D}, \mathrm{W}, \mathrm{A} \& \mathrm{C}- \\
\text { Macropodes }\end{array}$ & $\begin{array}{l}\text { N.A.F. Ellis, } 27 \text { September } 1882 \text { (Lectotype, } \\
\text { NY) }\end{array}$ & USA & JX993086 \\
\hline Wynnella silvicola & $\begin{array}{l}\mathrm{D}, \mathrm{W}-\text { Genus } \\
\text { Wynnella } \\
\text { A \& C - Subgenus } \\
\text { Silvicolae }\end{array}$ & N.S.Weber 6219 (OSC) & USA & ${ }^{\mathrm{k}} \mathrm{U} 42682$ \\
\hline
\end{tabular}


Table 1 (Continued)

\begin{tabular}{|c|c|c|c|c|}
\hline Species & Infrageneric position & Collection data, date (Herbarium) & $\begin{array}{l}\text { Country } \\
\text { of origin }\end{array}$ & $\begin{array}{l}\text { GenBank } \\
\text { (accession no.) }\end{array}$ \\
\hline $\begin{array}{l}\text { Wynnella silvicola } \\
\text { Balsamia magnata } \\
\text { Balsamia nigrens } \\
\text { Barssia oregonensis } \\
\text { Barssia oregonensis } \\
\text { Barssia cf. oregonensis } \\
\text { Choiromyces alveolatus } \\
\text { Discina macrospora } \\
\text { Gyromitra melaleucoides } \\
\text { Labyrinthomyces varius } \\
\text { Rhizina undulata } \\
\text { Tuber melanosporum } \\
\text { Tuber rufum } \\
\text { Underwoodia beatonii } \\
\text { Underwoodia beatonii } \\
\text { Underwoodia columnaris }\end{array}$ & Outgroup & N.S.Weber 6219 (OSC) & USA & $\begin{array}{l}\text { JX993087 } \\
\text { U42683 } \\
\text { EU669425 } \\
\text { U42684 } \\
\text { NG027601 } \\
\text { AY544652 } \\
\text { AF435826 } \\
\text { U42678 } \\
\text { U42680 } \\
\text { U42689 } \\
\text { Q220410 } \\
\text { AF435821 } \\
\text { DQ191676 } \\
\text { JQ925715 } \\
\text { JQ925716 } \\
\text { U42685 }\end{array}$ \\
\hline \multicolumn{5}{|c|}{$\begin{array}{l}\text { Symbology: D - Dissing (1966), W - Weber (1972), A \& C - Abbott and Currah (1997). } \\
\text { a From Tedersoo et al. (2006), included in the morphological study. } \\
\text { b As "H. leucomelaena" in Tedersoo et al. (2006). } \\
\text { c From Nguyen et al. (2013), not studied morphologically. } \\
\text { d From Tedersoo et al. (2006), not studied morphologically. } \\
\text { e From AFTOL (unpublished), not studied morphologically. } \\
\text { f As Helvella Sect. Crispa. In the case of the species not included by D, W, and A \& C, their location is in accordance with the morphologic characteristics of the } \\
\text { section. } \\
\text { g From Bonito et al. (2013), not studied morphologically. }\end{array}$} \\
\hline
\end{tabular}

\section{Updated generic description}

Helvella (as Elvela) L., Sp. pl. 2: 1180 (1753)

Type species: Helvella mitra (as Elvela) L., Sp. pl., Edn 2 2: 1180 (1753)

$\equiv$ Helvella crispa (Scop.) Fr., (Lundae) 2(1): 14 (1822)

Ascomata epigeous, stipitate, occasionally subsessile, solitary to gregarious. Apothecia cupulate, discoid, convex, saddle-shaped, bi-, tri-, or irregularly lobed, but never auricularioid nor completely fused with the stipe; hymenium white, cream, buff, brown, gray, red brown, dark brown, or black, occasionally mottled (shades of grayish brown); apothecial sterile surface smooth or ribbed, glabrous, subpubescent, or pubescent, same color as hymenium or lighter. Stipe terete, even, with clefts, costate, or lacunose, white, cream, buff, brown, gray, or black, glabrous, subpubescent, or pubescent, internally solid, hollow, or chambered; base with white mycelium. Asci cylindrical, hyaline, operculate, base pleurorhynchous or aporhynchous, non-amyloid (J-), 8-spored. Ascospores ellipsoid to broadly ellipsoid, subglobose, subfusoid to fusoid, frequently with a central guttule or rarely triguttulate, hyaline, smooth or verrucose, tetranucleate at maturity. Paraphyses straight, clavate, septate, simple or branched, normally thin-walled, rarely thickwalled or with a thick-walled cap or collar at the apex, hyaline, with light brown or dark brown pigments in the wall, cytoplasm, and/or encrusted on the wall, these pigments visible or not with cotton blue. Apothecial tissues divided in 2 layers: medullary and ectal excipulum; stipe tissues also separated in an outer and inner layer. Medullary excipulum and stipe inner layer of textura intricata, hyaline or light brown, some species with dextrinoid reaction $(\mathrm{Dx}+)$ with Melzer's reagent. Ectal excipulum and stipe outer layer of textura angularis, hyaline, with light or dark brown pigments in the wall, cytoplasm, and/or encrusted on the wall, pigments visible or not with cotton blue, some species Dx+. Hairs may be present on the apothecial sterile surface and on the stipe surface, with the same microstructure in all species that present them, grouping into hyphal clusters or fascicles, hyaline, light brown, or dark brown, pigments present in the wall, cytoplasm, and/or encrusted on the wall, pigments visible or not with cotton blue, some species Dx+. Basal mycelial hyphae septate, hyaline.

\section{Habit, habitat, and distribution}

Solitary or in groups, some scattered, in soil of conifer and angiosperm forests. Common in temperate and arctic habitats, almost exclusively distributed in the Northern Hemisphere; only Helvella elastica, $H$. fibrosa (Wallr.) Korf, $H$. lacunosa (sensu lato), H. papuensis Dissing, and H. sp. (aff. H. pezizoides) have been reported from a tropical region, in Papua New Guinea (Dissing, 1979). Some species have been cited from Argentina and Australasia (Gamundi, 2010; Rifai, 1968). 


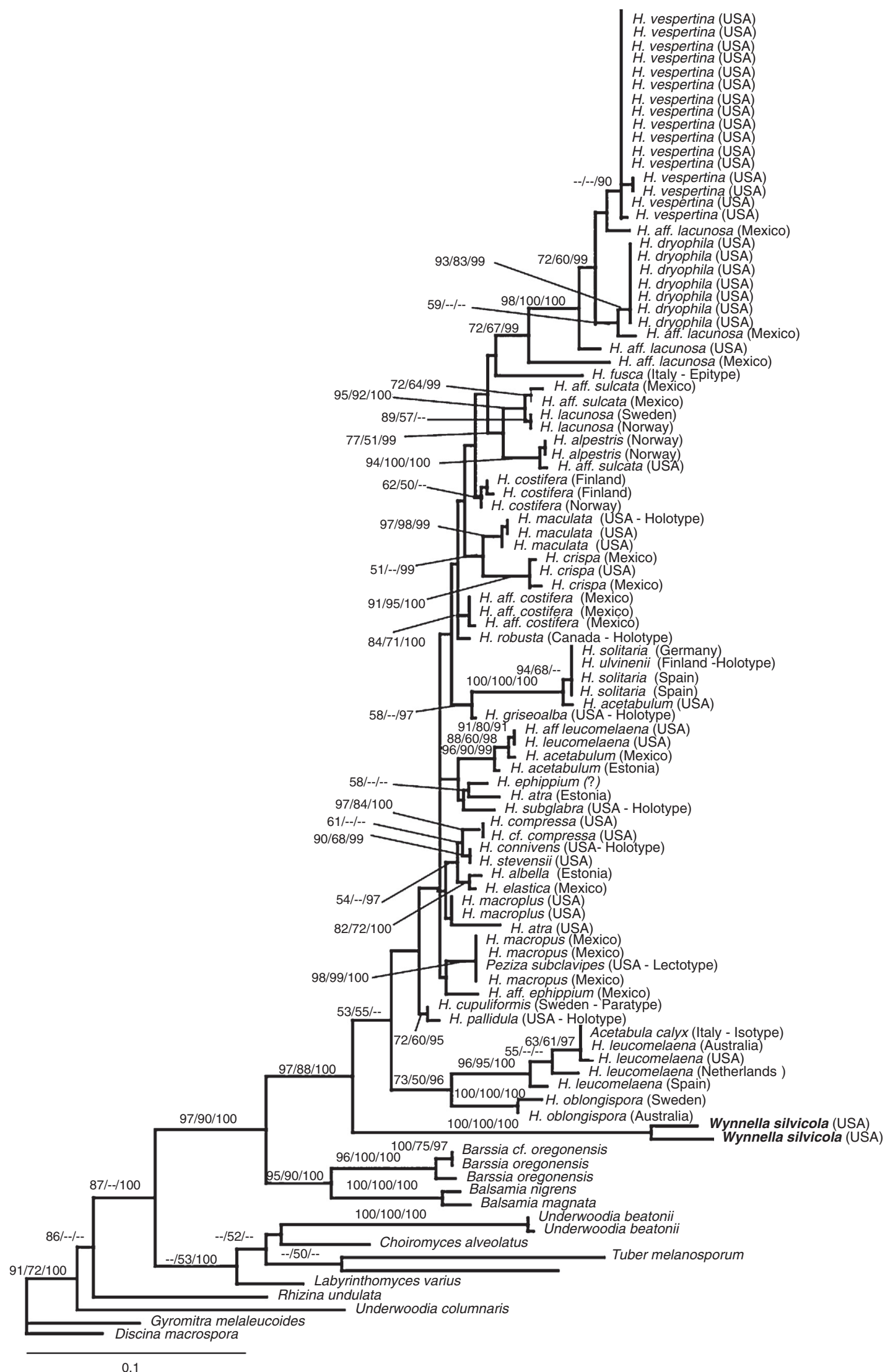

Figure 3. Phylogenetic position of Wynnella based on maximum parsimony analysis of large nuclear subunit rDNA sequences. Maximum likelihood bootstrap support (BML) and parsimony bootstrap support (BMP) $>50 \%$, and Bayesian posterior probability (PP) values $>95 \%$ are given at the internodes (BML/BMP/PP). 


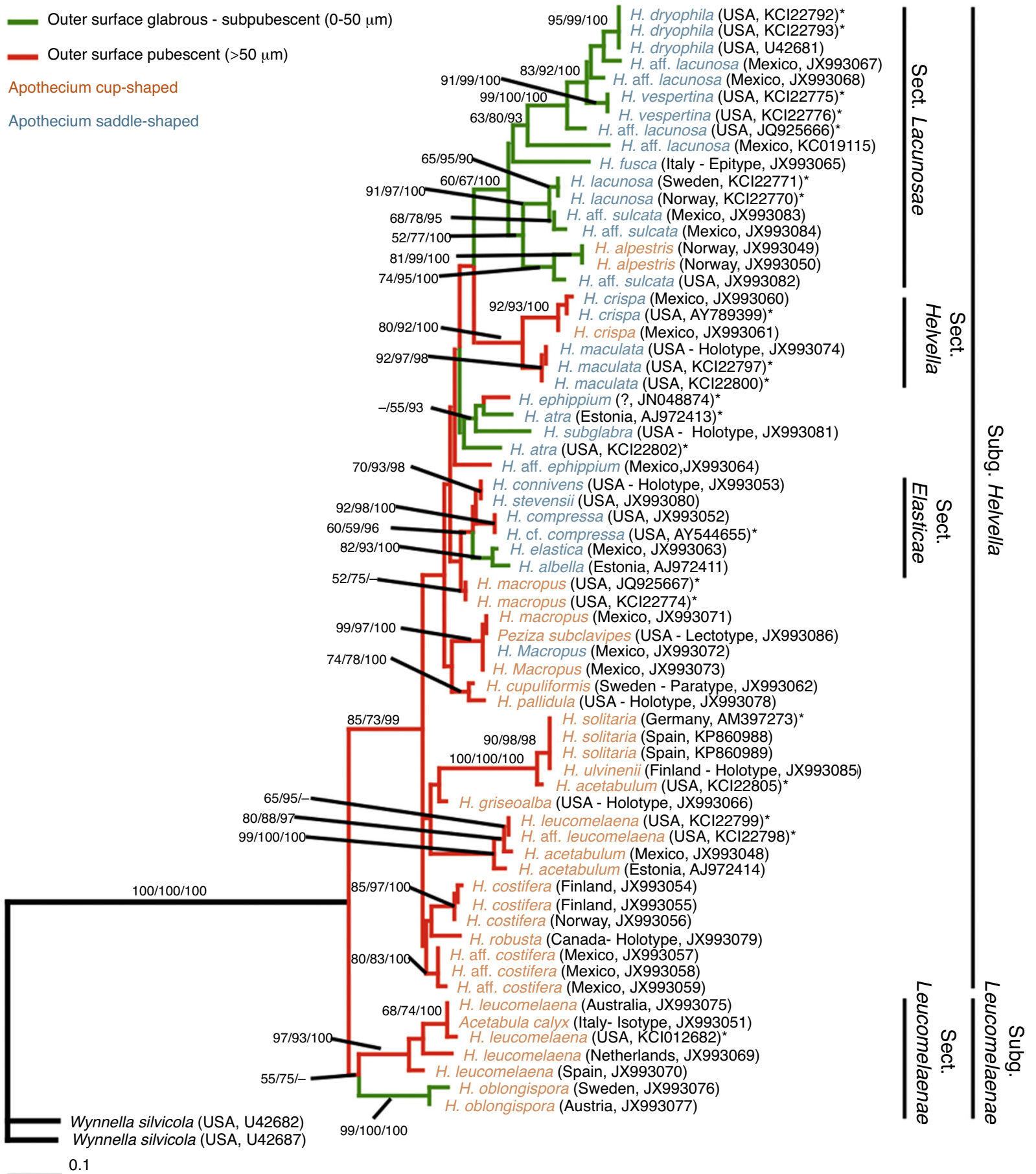

Figure 4. Phylogeny of Helvella generated from maximum likelihood analysis of large nuclear subunit rDNA sequences and morphological data. Maximum likelihood bootstrap support (BML), parsimony bootstrap support (BMP) $>50 \%$, and Bayesian posterior probability (PP) values $>95 \%$ are given at the internodes (BML/BMP/PP). *Specimens not studied morphologically.

\section{Discussion}

\section{The misunderstood concept of Helvella}

Since the last century, Nannfeldt (1937) argued that Acetabula (Fr.) Fuckel [represented here by Helvella acetabulum (L.) Quél.], Cyathipodia Boud. (represented here by H. cupuliformis Dissing \& Nannf.), Leptopodia Boud. (represented here by $H$. albella, $H$. alpestris, $H$. atra J. König, H. elastica,
H. ephippium Lév., and H. stevensii), Macropodia Fuckel or Macroscyphus Nees ex Gray [represented here by H. macropus (Pers.) P. Karst., Peziza subclavipes W. Phillips \& Ellis], and Paxina Kuntze (represented here by A. calyx, H. acetabulum, $H$. compressa, H. costifera Nannf., and H. leucomelaena in this paper) were untenable. They were described based on the shape of the apothecia and stipes, e.g., Macropodia with cup-shaped apothecia and Leptopodia with lobed apothecia. However, it is common to find ascomata with young cup-shaped apothecia that 
later become lobed (as in $H$. crispa and H. macropus). None of these genera can be separated from Helvella because they are: (1) microscopically similar, and (2) do not form supported monophyletic clades.

Some authors did not follow the Nannfeldt's concept of Helvella. Dennis (1981) and Breitenbach and Kränzlin (1984) continued using the genera Cyathipodia, Leptopodia, Macropodia or Macroscyphus, and Paxina, as well as Helvella. In contrast, Eckblad (1968) placed Underwoodia columnaris Peck and $U$. fuegiana (Speg.) Gamundi under Helvella, and this placement was followed by Harmaja (1974), who synonymized $U$. beatonii Rifai as $H$. beatonii (Rifai) Harmaja. However, Abbott and Currah (1997), Ainsworth, Sparrow, and Sussman (1973), Dissing (1966, 1972), Gamundi (2010), Korf (1972), and Rifai (1968), considered Underwoodia as an independent genus. Phylogenetic studies have corroborated the last point of view (Hansen \& Pfister, 2006; Læssøe \& Hansen, 2007; O’Donnell, Cigelnik, Weber, \& Trappe, 1997, and this work). Although Underwoodia has a medullary excipulum of textura intricata and ectal excipulum of textura angularis as do all species of Helvella, and this character was used by Eckblad (1968) to consider Underwoodia as a synonym of Helvella, the apothecium of Underwoodia is fully adhered to the stipe, unlike any apothecium seen in Helvella. Also, ascospore ornamentation is very evident inside the asci (not seen in Helvella ascospores), and some species have hooked paraphyses ( $U$. beatonii and $U$. columnaris), while all the species of Helvella have straight paraphyses.

The taxonomic position of Wynnella has been controversial. On the basis of microscopic features, Harmaja (1974) transferred W. silvicola to H. silvicola. Abbott and Currah (1988), following Harmaja, erected Helvella sect. Silvicolae to place this species. Subsequently, they raised its rank to subgenus (Abbott \& Currah, 1997). However, Ainsworth et al. (1973), Dissing (1966, 1972), Dissing, Eckblad, and Lange (2000), Eckblad (1968), Korf (1972), and Parslow and Spooner (2009) recognized Wynnella as an independent genus from Helvella. Phylogenetic studies of Helvellaceae have suggested a sister group relationship between Helvella and Wynnella (Hansen \& Pfister, 2006; Harrington, Pfister, Potter, \& Donoghue, 1999; Læssøe \& Hansen, 2007; Landvik, Kristiansen, \& Schumacher, 1999; O'Donnell et al., 1997), which was also found in this study. Like Underwoodia and Helvella, Wynnella has a medullary excipulum of textura intricata and ectal excipulum of textura angularis, but its apothecia are auriculoid (similar to a rabbit's ear), different to any apothecia seen in Helvella. A complete circumscription of Helvella based mainly on Nannfeldt (1937), Dissing (1966, 1972), and Rifai (1968), and following the phylogenetic results previously obtained and the ones generated in this study, is presented above in Results.

\section{Comments about diversity and distribution of the species of Helvella}

Excluding synonyms and species transferred to other genera, 36 species have been recognized for Europe (Calonge \& Arroyo, 1990; Dissing, 1966; Dissing et al., 2000; Häffner,
1987; Van Vooren, 2010). In North America, 32 species have been registered (Abbott \& Currah, 1997; Nguyen, Landeros, Garibay-Orijel, Hansen, \& Vellinga, 2013; Weber, 1972), 20 for Asia (Kaushal, 1991; Zhuang, 1995), 3 for South America (Dissing, 1966; Gamundi, 2010; Wright \& Albertó, 2006), 3 for Africa (Dissing, 1966), and 2 species for Australia (Rifai, 1968). Helvella leucomelaena is the most widely cited, recorded from every continent. Similarly, $H$. lacunosa and $H$. solitaria P. Karst. are located on 4 continents. However, it has recently been revealed that $H$. lacunosa is a complex of species, where the American specimens do not correspond to its European counterpart (Nguyen et al., 2013). This probably occurs with other species with a broad distribution such as H. leucomelaena and H. costifera as already seen from our data (Fig. 4), but we need more detailed studies to confirm it.

On the other hand, $H$. alpestris, $H$. dovrensis T. Schumach., H. fusca, H. latispora Boud., H. oblongispora, H. paraphysitorquata I. Arroyo \& Calonge, and H. ulvinenii Harmaja have been reported only from Europe (Calonge \& Arroyo, 1990; Dissing, 1966; Schumacher, 1992). Helvella compressa, H. crassitunicata N.S. Weber, H. griseoalba N.S. Weber, H. maculata, and $H$. robusta S.P. Abbott are exclusively known from America (Abbott \& Currah, 1997; Weber, 1972, 1975). Helvella papuensis is only recorded from a tropical region of Papua New Guinea (Dissing, 1979) and H. aestivalis (R. Heim \& L. Rémy) Dissing \& Raitv., H. dovrensis, and H. verruculosa (Berk. \& M.A. Curtis) Harmaja have an arctic and alpine distribution (Abbott \& Currah, 1997). It is necessary to examine Helvella species that have been described from Asia to determine their status.

\section{Infrageneric classification of Helvella}

The analysis combining DNA sequences, morphological, and chemical data generated trees with better-supported clades, which demonstrates the importance of "total evidence", where all relevant data are considered in phylogenetic analysis (Eernisse \& Kluge, 1993).

Our results do not completely support any previous infrageneric Helvella classification. However, there is enough current evidence to divide Helvella in 2 subgenera based on ascus development that is also supported by phylogenetic data (Fig. 4). Helvella subgen. Leucomelaenae is monotypic with sect. Leucomelaenae Dissing sensu Weber (1972) and includes species with aporhynchous asci. On the other hand, Helvella subgen. Helvella comprises species with pleurorhynchous asci. The present study failed to determine several species affinities at section level, as for $H$. acetabulum, $H$. costifera, $H$. griseoalba, $H$. robusta, and $H$. ulvinenii within Helvella sect. Acetabulum Dissing sensu Weber (1972). Although H. atra, H. ephippium, and H. subglabra N.S. Weber, representing Helvella sect. Ephippium Dissing sensu Weber (1972), formed a clade, this was unsupported statistically. Furthermore, the phylogenetic results did not support the association of the species of Helvella sect. Macropodes Dissing sensu Weber (1972), which includes $H$. cupuliformis and $H$. macropus. It is necessary to use other DNA regions to resolve their affinity. 
Most of the monophyletic clades are defined by more than one morphological feature. The exception is the clade representing Helvella sect. Leucomelaenae, which is characterized only by the presence of aporhynchous asci. Figure 4 shows that the main features used by Abbott and Currah (1997), Dissing (1966), and Weber (1972) to define infrageneric taxa (pubescence and apothecium shape) are present throughout the phylogram, and only in combination can they be used as diagnostic characters of the clades.

\section{Helvella subgen. Helvella}

$$
\text { \# subgen. Helvella, in Abbott and Currah (1997) }
$$

Asci pleurorhynchous, i.e., ascus base forked, because a crozier is formed at the base.

Type species: Helvella crispa (Scop.) Fr.

Abbott and Currah (1997) circumscribed subgen. Helvella for species with lobed apothecia and a costate or lacunose stipe; instead, we consider this subgenus to include all the species with pleurorhynchous asci. Phylogenetically supported sections in this subgenus are Elasticae, Helvella, and Lacunosae.

Helvella subgen. Leucomelaenae S.P. Abbott emend. Landeros \& Guzm.-Dáv.

Asci aporhynchous, i.e., ascus base simple, because no crozier is formed at the base.

Type species: Helvella leucomelaena (Pers.) Nannf.

It is characterized by its aporhynchous asci. In contrast, Abbott and Currah (1997) delineated the subgenus for species with a cup-shaped apothecium and a costate stipe, without considered how the ascus was formed. We recognize sect. Leucomelaenae Dissing sensu N.S. Weber (1972).

\section{Taxonomically informative features}

Comments on all the characters that have been used in Helvella are presented, mentioning if they have any taxonomical value.

Apothecia. Weber (1972) and Abbott and Currah (1997) considered the shape of the apothecia as one of the most important features for recognition of sections or subgenera within the genus. Helvella acetabulum, H. costifera, H. cupuliformis, $H$. ulvinenii, and $H$. verruculosa have cup-shaped apothecia throughout their entire development. In contrast, $H$. albella, $H$. compressa, H. elastica, and H. lacunosa exhibit lobed apothecia. However, some species like H. crispa, H. ephippium, and $H$. macropus have cupulate apothecia when young and lobed apothecia when mature, and sometimes even cupulate apothecia may have mature ascospores. Another relevant taxonomic character is the way in which the apothecium margin is attached to the stipe, a feature almost exclusively found in sect. Lacunosae and in $H$. robusta in sect. Acetabulum. Therefore, the classification of Helvella based on apothecia shape and attachment is problematic. In the light of the phylogenetic results (Fig. 4), it is desirable to re-evaluate these characters more carefully in each species by studying various collections and assessing the degree of variation.

Stipe. Its shape is a diagnostic character in the genus. Weber (1972) described the stipe as even, costate, lacunose, and sulcate. The first 3 are easy to distinguish, but sulcate is hard to differentiate from costate. For this reason, we consider sulcate and costate as synonyms, meaning that the stipe has only longitudinal ribs. Sometimes species with a smooth stipe can develop folds or clefts mainly in old ascomata [e.g., Helvella atra, H. corium (O. Weberb.) Massee, H. pezizoides Afzel., H. stevensii], but they never look like true ribs as in $H$. acetabulum, H. costifera, and H. sulcata Afzel. On the other hand, H. costifera, $H$. palustris Peck, and $H$. sulcata have a costate stipe with one or 2 transverse ribs, but it never looks like a lacunose stipe, which has both longitudinal and tranversal ribs, giving the stipe the appearance of having deep holes, e.g., in H. lacunosa. Because we have seen specimens of H. acetabulum and H. crispa with either costate or lacunose stipes, we believe it is important to know the degree of variation among and within species. Therefore, we consider stipe shape (even, costate, and lacunose) as an important taxonomic character.

Hymenium and stipe color. Weber (1972) regarded hymenium and stipe color as valuable features at the infrageneric classification level, while Abbott and Currah (1997) did not use these as main characters for their sections. We agree with Weber (1972) that hymenium and stipe colors are useful, but only for species distinction and in combination with other characters. For instance, Helvella sect. Elasticae Dissing sensu Weber (1972) is defined by its tan to gray-brown hymenial surface and buff to nearly white stipe, besides the lobed apothecium and even stipe. Hymenium color is also helpful for identifying species. For example, fresh specimens of $H$. griseoalba have a hymenium with grayish tones, which separates them from fresh specimens of $H$. costifera, which have brownish tones.

Ribs. Rib structure is a useful character to distinguish some species. In Helvella acetabulum, sharp ribs contrast with the blunt ribs of $H$. costifera and $H$. griseoalba. Another feature to take into consideration is the distance from the ribs to the margin of the apothecial sterile surface. We recognize 2 categories in this character: (1) ribs missing or reaching a quarter or less in the lower part of sterile surface (e.g., $H$. leucomelaena, $H$. solitaria, and $H$. sulcata), and (2) ribs reaching half or to the edge of the apothecium, i.e., in the same ascoma of $H$. acetabulum or $H$. costifera ribs may arrive halfway, some to three quarters, and others to the edge of the apothecial sterile surface. Although ribs can be simple, forked, or anastomosing, this feature is uninformative because some species have simple ribs when immature and forked when mature, or in the same stage ribs may be both simple and forked.

Asci. Weber (1972) considered ascus development (aporhynchous vs. pleurorhynchous) as a useful character. Indeed, she restricted Helvella sect. Leucomelaenae to include only species with aporhynchous asci. In this work, we found that Helvella 
sect. Leucomelaenae Dissing sensu Weber (1972) is monophyletic (Fig. 4), with aporhynchous asci its synapomorphy.

Ascospores. Ascospores have little taxonomic value, except in a few species of Helvella. Helvella crassitunicata and H. pocillum Harmaja have large ascospores (Landeros et al., 2012). Likewise, H. macropus and H. terrestris (Velen.) Landvik develop fusoid to subfusoid ascospores (Abbott \& Currah, 1997; Landvik et al., 1999). Abbott and Currah (1997) established ascospore ornamentation as an important taxonomic feature. Unfortunately, ornamentation is variable among ascospores of the same species. The verrucose appearance is due to remnants of the secondary wall of the ascospores, which might adhere to the primary wall (Schumacher, pers. com. in Landeros et al., 2012). It is common in many ascospores of the same specimen that such remnants do not adhere, and therefore, ascospores remain smooth. For this reason, Eckblad (1968) described the ascospores of Helvella as having "false ornamentation".

Paraphyses. Their shape is useful at the generic level in Helvellaceae, but not for infrageneric classification or to separate species. In Helvella, all species have septate, simple or branched, and straight paraphyses, in at least one stage of their development. Vite-Garín, Villaruel-Ordaz, and Cifuentes (2006) described species with non-septate (e.g., H. acetabulum, $H$. corium, $H$. cupuliformis, and $H$. elastica) and/or unbranched paraphyses (e.g., H. acetabulum, H. atra, H. corium, H. costifera, and $H$. crispa). We studied some of the specimens Vite-Garín et al. (2006) mentioned and found that paraphyses are always septate and either branched or unbranched in the same specimen.

Hyphal fascicles. Microscopically, hairs on the apothecial surface are formed by hyphal fascicles. In the present work, following Landeros et al. (2012), we use the terms: (1) glabrous, when such hyphal fascicles are absent; (2) subpubescent, when hyphal fascicles are shorter than $50 \mu \mathrm{m}$; and (3) pubescent, when hyphal fascicles are longer than $50 \mu \mathrm{m}$. Dissing (1966) considered hairs on the apothecial sterile surface as an important criterion in his infrageneric classification. In Figure 4, all species of Helvella sect. Lacunosae are glabrous-subpubescent, while all species of sections Helvella and Macropodes (H. cupuliformis and H. macropus) are pubescent. However, in Helvella sect. Elasticae sensu Dissing (1966) there are species with glabrous, subpubescent, and pubescent ascomata. In this case, this feature is useful to recognize species, such as $H$. albella and $H$. elastica, which have a glabrous to subpubescent surface. Therefore, this is an important feature for recognizing species, but it must be used in conjunction with other characteristics to separate sections.

Pigments. For Landeros et al. (2012), the presence of pigment in the ascoma has taxonomic value at species level. When present, pigments have to be evaluated from 3 points of view: (1) color, which may vary from dark to light brown; (2) structure location, pigments can be found in paraphyses, ectal excipulum cells, stipe outer layer cells, and apothecial and stipe hyphal fascicles, and (3) cellular location, in the wall, encrusted on the wall, and/or in the cytoplasm. We also recommend using cotton blue to evaluate whether the pigments are visible or not with this stain. Encrusted pigment on the wall (mainly in the paraphyses) is variable between ascomata of the same species; if present, it is always visible with cotton blue.

Dextrinoid reaction $(D x+)$. A red reaction in Melzer's reagent, assessed according to Leonard (2006), is a meaningful character from taxonomic and phylogenetic perspectives. All species of Helvella sect. Elasticae present at least one Dx+ tissue, but this feature is not exclusive to this section; e.g., H. acetabulum, $H$. robusta, and $H$. subglabra also have at least one type of Dx+ tissue, and the reaction can be used to recognize these species. Because the reaction is especially evident in stipe tissues, it is important to look in the entire ascoma for it and to describe the tissue where it occurs.

Cell width in the ectal excipulum and stipe outer layer, and breadth of both layers. We noticed that cell width in the ectal excipulum and outer stipe layer of each ascomata is the same, independent of the tissue origin of the section. The thickness of the ectal excipulum may vary slightly; it is thinner toward the edge and wider in the center of the apothecium, while in the stipe the outer layer is uniform. Helvella oblongispora is unique in these layers being very wide, both composed of very large cells, almost the same width as in the medullary excipulum. Therefore, this feature is only important for recognizing $H$. oblongispora.

Ecology. Hobbie, Weber, and Trappe (2001) mentioned as uncertain the mycorrhizal status of Helvella; however, Tedersoo, Hansen, Perry, and Kjøller (2006) considered all the species as forming ectomycorrhizae, hence studies are needed to confirm the status of the genus. Some taxa are associated with specific trees, e.g., H. fusca (Dissing, 1966; Landeros et al., 2012) and H. leucopus var. populina I. Arroyo \& Calonge (in Calonge, 2000) always grow near or under Populus L. Recently, on the basis of molecular data, 2 cryptic species of the $H$. lacunosa complex from western North America were found (Nguyen et al., 2013); H. dryophila is associated with Quercus L. and $H$. vespertina with conifers. Furthermore, Helvella species can be restricted to a vegetation type or ecosystem, e.g., H. papuensis associates with tree species of Castanopsis (D. Don) Spach and Lithocarpus Blume in subtropical rain forests (Abbott \& Currah, 1997; Dissing, 1979) and H. aestivalis and H. verruculos $a$ in the tundra of arctic and alpine regions (Abbott \& Currah, 1997).

Phenology is also cited as an important feature; $H$. ephippium fruits in July and August in USA (Weber, 1972) and H. leucopus Pers. from March to May in Europe (Dissing, 1966). The fruiting period can also be longer; $H$. elastica, H. lacunosa, and H. macropus fruit from June to November (Dissing, 1966; Weber, 1972). Some species fruit at different times in different countries; $H$. leucomelaena fruits from May to July in Sweden, from January to May in France, from April to June in British Columbia and Washington, and from May to September in Alberta (Abbott \& Currah, 1997; Dissing, 1966). There are species that can be distinguished from other similar species on the basis of phenology; $H$. albella has an autumnal fruiting pattern, whereas $H$. compressa fruits in the spring. In 
addition to the information of vegetation and phenology, soil type was proposed by Dissing (1966) as an important feature to recognize some species. For example, he described $H$. corium, $H$. leucomelaena, H. queletii Bres., and H. solitaria growing in calcareous soil.

\section{Species complex and misunderstood species}

Helvella alpestris. This species is cited in Index Fungorum (2015) as a synonym of $H$. corium (O. Weberb.) Massee, but we treat it as an independent species, as Mycobank (2015). Boudier (1895) described H. alpestris with ascospores 22-25 × 14-15 $\mu \mathrm{m}$, stipe "sulcatum" (ribbed) and "... extus sub lente breviter velutinum, non squamoso-hirtum" (under lens surface slightly velutinous, non squamous-hirsute). Dissing (1966) considered $H$. alpestris as a synonym of $H$. corium, with ascospores 18-20-22 × 11-12.1-13 $\mu \mathrm{m}$, stipe with grooves near the base, and surface pubescent to villose, which, according to Boudier's protologue corresponds to an incorrect interpretation of $H$. alpestris. Later, Häffner (1987) separated both species, describing $H$. corium with ascospores (15.3-) 17.3-21.3 $(-22) \times(8.5-) 9-12.7 \mu \mathrm{m}$, stipe even, and pubescent apothecial sterile surface. For Häffner, H. alpestris has ascospores (15-) 17-20.5 (-22.1) × 10.2-13.3 $\mu \mathrm{m}$, stipe with well-defined ribs, and glabrous to subpubescent apothecial sterile surface. Except for the ascospore size, the interpretation of Häffner matches Boudier's description of $H$. alpestris. The specimens that we studied and sequenced have ascospores similar to those cited by Häffner; hence, in this paper we follow this interpretation. However, it is necessary to sequence material of $H$. corium to confirm if they are different.

Helvella atra. Landeros et al. (2012) mentioned several features to distinguish this species from $H$. subglabra. Furthermore, in the tree of Figure 4, the sequences of 2 specimens of $H$. atra from the USA are not grouped together, indicating that another species could be split. Therefore, it is necessary to include specimens from other parts of the world in the analyses, mainly from Europe, as $H$. atra was described from Iceland, to elucidate its status and typify it because there is no type material.

Helvella costifera. This species was described by Nannfeldt (in Lundell \& Nannfeldt, 1953) from Sweden. Later, Weber (1972) described H. griseoalba and Harmaja (1978) H. hyperborea Harmaja. Landeros et al. (2012), with a study of the type specimens and additional material, proposed that $H$. hyperborea is a synonym of $H$. costifera, but $H$. griseoalba is an independent species. We sequenced European specimens from Finland and Norway and found that they grouped in one supported clade (Fig. 4), except the holotype of $H$. griseoalba, which agrees with Landeros et al. (2012). In fact, H. griseoalba is closer to the $H$. solitaria clade than to any member of $H$. costifera group. On the other hand, there is a species complex, formed by European specimens that correspond to $H$. costifera and Mexican specimens belonging to a different undescribed species (Fig. 4).

Helvella ephippium. This species has a small apothecium, less than $1.5 \mathrm{~cm}$ diam. Only $H$. pocillum, $H$. rivularis Dissing
\& Sivertsen, and $H$. terrestris can be as small, but all these species have a cup-shaped, well-defined apothecium, while $H$. ephippium has an involute, irregularly lobed to saddle-shaped apothecium. Léveillé (1841) did not mention the size of the ascospores, he only wrote "rondes et transparentes". Massee (1895) was the first to describe them, $16-18 \times 10 \mu \mathrm{m}$. More recently, Dissing (1966) measured ascospores 19-20.4-21.5 × 11-11.6-12 $\mu \mathrm{m}$, while Weber (1972) described them as $16.5-19 \times 10.5-12 \mu \mathrm{m}$ and Abbott and Currah (1997) as 17-21 × 10.1-13 $\mathrm{m}$. We included 2 sequences in our analyses, one as $H$. ephippium from Europe (unfortunately with no more information on locality and collector) (Alvarado et al., 2011), and another as $H$. aff. ephippium from Mexico, which we proved to be unrelated (Fig. 4). On the basis of this phylogenetic result and the differences in ascospore size found by different authors, we think it is a complex. Thus, it is necessary to first lectotypify $H$. ephippium with the figure of Léveillé (1841) and then epitypify it with a specimen to clarify this group of species.

Helvella fibrosa $[=H$. villosa (Hedw. ex Kuntze) Dissing \& Nannf.]. Not shown in the phylogenetic tree. Korf (2008) concluded that Peziza fibrosa is the correct name for this species because " $H$. villosa (Hedw. ex Kuntze) Dissing and Nannf." is a later homonym of a name proposed by Schaeffer (1774) for a different species. Also, Korf (2008) designated Hedwig's figure as the lectotype of $H$. fibrosa and specimen of Lundell, Nannfeldt, and Holm (Fungi exsiccate Suecici praesertim Upsaliensis \# 3262, 1985) as the epitype. On the other hand, Weber (1972) proposed $H$. pallidula N.S. Weber as a new taxon based on the absence of pigmentation in the ascoma tissues. We agree with Häffner (1987) and Abbott and Currah (1997), in considering $H$. pallidula as a synonym of $H$. fibrosa because when we studied the holotype of the former we observed light brown pigments in the paraphyses, ectal excipulum, and outer layer of stipe, and yellowish pigments in the apothecial and hyphal fascicles of the stipe, as in H. fibrosa It is necessary to include sequences of specimens from several countries in different continents in the phylogenetic analyses to establish if all specimens cited as $H$. fibrosa correspond to the same species.

Helvella lacunosa and $H$. sulcata. These 2 species were described by Afzelius (1783). Since the last century, their delimitation has been controversial, being considered as synonyms (Abbott \& Currah, 1997; Dissing, 1966; Häffner, 1987) and as separate taxa (Landeros \& Guzmán-Dávalos, 2013; Weber, 1972). Recently, 2 species of the H. lacunosa complex in the western USA were segregated and described (Nguyen et al., 2013) because their DNA sequences do not correspond to the European material of this species. A careful study is needed to determine the number of species included in this complex and to elucidate the status of some species such as H. sulcata.

Helvella leucomelaena. We sequenced 4 specimens of this species (Table 1), 3 from Europe (one of them labeled as the isotype of Acetabula calyx) and one from Australia, and all were grouped in a supported clade (Fig. 4). Acetabula calyx is cited in the Index Fungorum (2015) as a synonym 
of $H$. solitaria; however, morphological data and LSU rDNA sequence of the isotype, indicate that it must be a synonym of H. leucomelaena. Of 4 sequences labeled as $H$. leucomelaena in GenBank (AJ972414, KC012682, KC122799, KC122798), only one (KC012682 from US) grouped with our sequences of this species (Fig. 4). We checked the source specimen [Bellis Kullman, 21 May 2001 (TAA179637, TAAM)] for sequence AJ972414 and found pleurorhynchous asci, so it corresponds to H. acetabulum; in fact, AJ972414 groups with $H$. acetabulum from Mexico and Estonia. We did not study the US specimens from which sequences KC122798 and KC122799 were obtained; thus, we do not know whether they have aporhynchous or pleurorhynchous asci, but we suspect they correspond to H. acetabulum in their phylogenetic position (Fig. 4). Harmaja (1977, 1978, 1979) proposed H. confusa Harmaja, H. oblongispora, and $H$. pedunculata Harmaja, which are very similar to H. leucomelaena. After morphologically studying the holotype of $H$. confusa (unpublished data) and specimens labeled as H. pedunculata by Harmaja (unpublished data), we have concluded that we do not have evidence to consider these 2 species as independent taxa. On the other hand, we sequenced 2 specimens labeled as $H$. oblongispora, one of them determined by Harmaja, and they were grouped in another clade, thus corroborating the observations of Abbott and Currah (1997), who considered $H$. confusa and $H$. pedunculata as synomyms of $H$. leucomelaena, but $H$. oblongispora as an independent taxon.

Helvella macropus. It can be identified by its fusoid to subfusoid ascospores within the asci. Helvella terrestris also has fusoid to subfusoid ascospores, but larger, 50-65 × 12-15 $\mu \mathrm{m}$ (Landvik et al., 1999) instead of $20-26 \times 9-12 \mu \mathrm{m}$ in $\mathrm{H}$. macropus (Dissing, 1966). Peck (1902) proposed H. macropus var. brevis Peck, based on specimens with smaller ascomata, with darker hymenia, and very short stipes. Later, Harmaja (1974) elevated it as $\mathrm{H}$. brevis (Peck) Harmaja, considering the ascospore size and ecological features (Weber, 1972), as did Abbott and Currah later (1988). However, Weber (1972) argued that the variation between the 2 taxa merely represents different responses to environmental conditions. In fact, later Abbott and Currah (1997) reconsidered their position and placed $H$. brevis in synonymy with $H$. macropus. Figure 4 shows that specimens of H. macropus from USA and Mexico do not form a clade; thus, future studies need to include European sequences of H. macropus to determinate its relation with the American specimens.

Helvella stevensii. This species was considered a synonym of H. latispora by Häffner (1987) and Abbott and Currah (1997), but we agree with Dissing (1966) in considering these species as independent taxa (see discussion by Landeros \& GuzmánDávalos, 2013). On another hand, we studied authentic material of $H$. stevensii and the holotype of $H$. connivens, but we did not find any difference. In fact, their DNA sequences are identical; therefore, we agree with Weber (1972) and Abbott and Currah (1997) that H. connivens is the same as H. stevensii.

DNA sequences of $H$. latispora specimens from Europe need to be analyzed to determine the relation of this species to H. stevensii in section Elasticae.

\section{Acknowledgments}

To the curators of the herbaria DAOM, ENCB, FCME, FH, H, IBUG, K, MA, MICH, NY, O, OSC, OULU, PRM, S, TAAM, UPS, WTU, and XAL for the loan of types and other specimens. The first author thanks the Universidad Autónoma de Querétaro for its support and Conacyt for a scholarship grant for his doctoral studies. To Greg Bonito (Duke University, USA) for providing literature on Helvella and Richard Korf (Cornell University, USA) for his nomenclatural advice and correcting a first draft of the manuscript. Funds were obtained from Universidad de Guadalajara (projects 72640, 88682, 108721, PIFI 2008-2009).

\section{Appendix I. Codification of morphological and chemical characters}

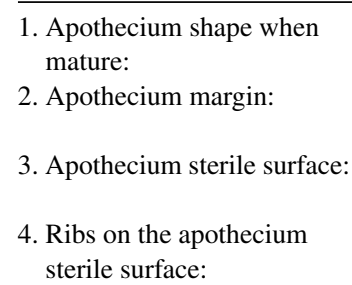

7. Edge of the ribs on the spite:

8. Stipe surface:

9. Stipe color:

10. Ascus type:

11. Reaction to Melzer's solution of apothecium medullary excipulum:

12. Reaction to Melzer's solution of apothecium ectal excipulum:

13. Reaction to Melzer's solution of stipe inner layer:

14. Reaction to Melzer's solution of stipe outer layer:

15. Ascospores shape:

\author{
(0) auriculoid, \\ (1) cup-shaped, (2) lobed \\ (0) free, (1) attached to the \\ stipe \\ (0) glabrous to subpubescent, \\ (1) pubescent \\ (0) missing or reaching only \\ up to $1 / 4$ of the surface, \\ (1) reaching from $1 / 4$ to the \\ apothecium edge \\ (0) ribbed, (1) even \\ (0) only longitudinal ribs, \\ (1) with longitudinal and \\ transversal ribs (forming \\ cavities, lacunose) \\ (0) sharp, (1) blunt \\ (0) glabrous to subpubescent, \\ (1) pubescent \\ (0) dark tones, (1) light tones \\ (0) pleurorhynchous, \\ (1) aporhynchous \\ (0) negative, (1) dextrinoid
}

(0) negative, (1) dextrinoid

(0) negative, (1) dextrinoid

(0) negative, (1) dextrinoid

(0) ellipsoid, (1) fusoid to subfusoid 
Appendix II. Matrix of morphological and chemical data.

\begin{tabular}{|c|c|c|c|c|c|c|c|c|c|c|c|c|c|c|c|}
\hline & 1 & 2 & 3 & 4 & 5 & 6 & 7 & 8 & 9 & $\begin{array}{l}1 \\
0\end{array}$ & $\begin{array}{l}1 \\
1\end{array}$ & $\begin{array}{l}1 \\
2\end{array}$ & $\begin{array}{l}1 \\
3\end{array}$ & $\begin{array}{l}1 \\
4\end{array}$ & $\begin{array}{l}1 \\
5\end{array}$ \\
\hline Wynnella silvicola JX993087 & 0 & 0 & 0 & 0 & 0 & 0 & 0 & 0 & 0 & 0 & 0 & 0 & 0 & 0 & 0 \\
\hline Wynnella silvicola U42682 & 0 & 0 & 0 & 0 & 0 & 0 & 0 & 0 & 0 & 0 & 0 & 0 & 0 & 0 & 0 \\
\hline Acetabula calyx JX993051 & 1 & 0 & 1 & 0 & 0 & 0 & 0 & 1 & 0 & 1 & 0 & 0 & 0 & 0 & 0 \\
\hline H. acetabulum JX993048 & 1 & 0 & 1 & 1 & 0 & 1 & 1 & 1 & 0 & 0 & 1 & 1 & 1 & 1 & 0 \\
\hline H. acetabulum AJ972414 & 1 & 0 & 1 & 1 & 0 & 1 & 1 & 1 & 0 & 0 & 1 & 1 & 1 & 1 & 0 \\
\hline H. acetabulum $\mathrm{KC} 122805$ & $?$ & $?$ & $?$ & $?$ & $?$ & $?$ & $?$ & $?$ & $?$ & $?$ & $?$ & $?$ & $?$ & $?$ & $?$ \\
\hline H. albella AJ972411 & 2 & 0 & 0 & 0 & 1 & $?$ & ? & 0 & 0 & 0 & 1 & 0 & 0 & 0 & 0 \\
\hline H. alpestris JX993049 & 2 & 0 & 0 & 0 & 0 & 0 & 0 & 0 & 0 & 0 & 0 & 0 & 1 & 0 & 0 \\
\hline H. alpestris JX993050 & 2 & 0 & 0 & 0 & 0 & 0 & 0 & 0 & 0 & 0 & 0 & 0 & 1 & 0 & 0 \\
\hline H. atra AJ972413 & 2 & 0 & $?$ & 0 & 1 & $?$ & $?$ & $?$ & $?$ & 0 & $?$ & $?$ & $?$ & $?$ & 0 \\
\hline H. atra $\mathrm{KC} 122802$ & 2 & 0 & $?$ & 0 & 1 & $?$ & $?$ & $?$ & $?$ & 0 & $?$ & $?$ & $?$ & $?$ & 0 \\
\hline H. compressa JX993052 & 2 & 0 & 1 & 0 & 1 & $?$ & $?$ & 1 & 0 & 0 & 1 & 1 & 1 & 0 & 0 \\
\hline H. cf compressa AY544655 & $?$ & $?$ & $?$ & $?$ & $?$ & $?$ & $?$ & $?$ & $?$ & $?$ & $?$ & $?$ & $?$ & $?$ & $?$ \\
\hline H. connivens JX993053 & 2 & 0 & 1 & 0 & 1 & $?$ & $?$ & 1 & 0 & 0 & 1 & 0 & 1 & 0 & 0 \\
\hline H. costifera JX993054 & 1 & 0 & 1 & 1 & 0 & 0 & 0 & 1 & 0 & 0 & 0 & 0 & 0 & 0 & 0 \\
\hline H. costifera JX993055 & 1 & 0 & 1 & 1 & 0 & 0 & 0 & 1 & 0 & 0 & 0 & 0 & 0 & 0 & 0 \\
\hline H. costifera JX993056 & 1 & 0 & 1 & 1 & 0 & 0 & 0 & 1 & 0 & 0 & 0 & 0 & 0 & 0 & 0 \\
\hline H. aff costifera JX993057 & 1 & 0 & 1 & 1 & 0 & 0 & 0 & 1 & 0 & 0 & 0 & 0 & 0 & 0 & 0 \\
\hline H. aff costifera JX993058 & 1 & 0 & 1 & 1 & 0 & 0 & 0 & 1 & 0 & 0 & 0 & 0 & 0 & 0 & 0 \\
\hline H. aff costifera JX993059 & 1 & 0 & 1 & 1 & 0 & 0 & 0 & 1 & 0 & 0 & 0 & 0 & 0 & 0 & 0 \\
\hline H. crispa JX993060 & 2 & 0 & 1 & 0 & 0 & 1 & 1 & 1 & 0 & 0 & 0 & 0 & 0 & 0 & 0 \\
\hline H. crispa JX993061 & 2 & 0 & 1 & 0 & 0 & 0 & 1 & 1 & 0 & 0 & 0 & 0 & 0 & 0 & 0 \\
\hline H. crispa AY789399 & 2 & 0 & 1 & $?$ & 0 & $?$ & 1 & 1 & 0 & 0 & $?$ & $?$ & $?$ & $?$ & 0 \\
\hline H. cupuliformis JX993062 & 1 & 0 & 1 & 0 & 1 & $?$ & $?$ & 1 & 0 & 0 & 0 & 0 & 0 & 0 & 0 \\
\hline H. dryophila $\mathrm{KC} 122793$ & $?$ & $?$ & $?$ & $?$ & $?$ & $?$ & $?$ & $?$ & $?$ & $?$ & $?$ & $?$ & $?$ & $?$ & $?$ \\
\hline H. dryophila $\mathrm{KC} 122792$ & $?$ & $?$ & $?$ & $?$ & $?$ & $?$ & $?$ & $?$ & $?$ & $?$ & $?$ & $?$ & $?$ & $?$ & $?$ \\
\hline H. dryophila U42681 & 2 & 1 & 0 & 1 & 0 & 1 & 1 & 0 & 0 & 0 & 1 & 0 & 0 & 0 & 0 \\
\hline H. elastica JX993063 & 2 & 0 & 0 & 0 & 1 & $?$ & $?$ & 0 & 0 & 0 & 1 & 0 & 1 & 0 & 0 \\
\hline H. ephippium JN048874 & $?$ & $?$ & $?$ & $?$ & $?$ & $?$ & $?$ & $?$ & $?$ & $?$ & $?$ & $?$ & $?$ & $?$ & $?$ \\
\hline H. aff. ephippium JX993064 & 2 & 0 & 1 & 0 & 1 & $?$ & $?$ & 1 & 1 & 0 & 0 & 0 & 0 & 0 & 0 \\
\hline H. fusca JX993065 & 2 & 1 & 0 & 1 & 0 & 1 & 1 & 0 & 0 & 0 & 0 & 0 & 0 & 0 & 0 \\
\hline H. griseoalba JX993066 & 1 & 0 & 1 & 1 & 0 & 0 & 0 & 0 & 0 & 0 & 0 & 0 & 0 & 0 & 0 \\
\hline H. lacunosa $\mathrm{KC} 122771$ & $?$ & $?$ & $?$ & $?$ & $?$ & $?$ & $?$ & $?$ & $?$ & $?$ & $?$ & $?$ & $?$ & $?$ & $?$ \\
\hline H. lacunosa KC122770 & $?$ & $?$ & $?$ & $?$ & $?$ & $?$ & $?$ & $?$ & $?$ & $?$ & $?$ & $?$ & $?$ & $?$ & $?$ \\
\hline H. aff. lacunosa JX993067 & 2 & 1 & 0 & 1 & 0 & 1 & 1 & 0 & 0 & 0 & 1 & 0 & 0 & 0 & 0 \\
\hline H. aff. lacunosa JX993068 & 2 & 1 & 0 & 1 & 0 & 1 & 1 & 0 & 0 & 0 & 1 & 0 & 0 & 0 & 0 \\
\hline H. aff. lacunosa KC019115 & 2 & 1 & 0 & 1 & 0 & 1 & 1 & 0 & 1 & 0 & 0 & 0 & 0 & 0 & 0 \\
\hline H. aff. lacunosa JQ925666 & $?$ & $?$ & $?$ & $?$ & $?$ & $?$ & $?$ & $?$ & $?$ & $?$ & $?$ & $?$ & $?$ & $?$ & $?$ \\
\hline H. leucomelaena JX993069 & 1 & 0 & 1 & 0 & 0 & 0 & 0 & 1 & 0 & 1 & 0 & 0 & 0 & 0 & 0 \\
\hline H. leucomelaena JX993070 & 1 & 0 & 1 & 0 & 0 & 0 & 0 & 1 & 0 & 1 & 0 & 0 & 0 & 0 & 0 \\
\hline H. leucomelaena JX993075 & 1 & 0 & 1 & 0 & 0 & 0 & 0 & 1 & 0 & 1 & 0 & 0 & 0 & 0 & 0 \\
\hline H. leucomelaena KC012682 & $?$ & $?$ & $?$ & $?$ & $?$ & $?$ & $?$ & $?$ & $?$ & $?$ & $?$ & $?$ & $?$ & $?$ & $?$ \\
\hline H. leucomelaena KC122799 & $?$ & $?$ & $?$ & $?$ & $?$ & $?$ & $?$ & $?$ & $?$ & $?$ & $?$ & $?$ & $?$ & $?$ & $?$ \\
\hline H. aff. leucomelaena $\mathrm{KC} 122798$ & $?$ & $?$ & $?$ & $?$ & $?$ & $?$ & $?$ & $?$ & $?$ & $?$ & $?$ & $?$ & $?$ & $?$ & $?$ \\
\hline H. macropus JX993071 & 1 & 0 & 1 & 0 & 1 & $?$ & $?$ & 1 & 1 & 0 & 0 & 0 & 0 & 0 & 1 \\
\hline H. macropus JX993072 & 1 & 0 & 1 & 0 & 1 & $?$ & $?$ & 1 & 1 & 0 & 0 & 0 & 0 & 0 & 1 \\
\hline H. macropus JX993073 & 1 & 0 & 1 & 0 & 1 & $?$ & $?$ & 1 & 1 & 0 & 0 & 0 & 0 & 0 & 1 \\
\hline H. macropus JQ925667 & $?$ & $?$ & $?$ & $?$ & $?$ & $?$ & $?$ & $?$ & $?$ & $?$ & $?$ & $?$ & $?$ & $?$ & $?$ \\
\hline H. macropus KC122774 & $?$ & $?$ & $?$ & $?$ & $?$ & $?$ & $?$ & $?$ & $?$ & $?$ & $?$ & $?$ & $?$ & $?$ & $?$ \\
\hline H. maculata JX993074 & 2 & 0 & 1 & 1 & 0 & 1 & 1 & 1 & 0 & 0 & 0 & 0 & 0 & 0 & 0 \\
\hline H. maculata $\mathrm{KC} 122800$ & $?$ & $?$ & $?$ & $?$ & $?$ & $?$ & $?$ & $?$ & $?$ & $?$ & $?$ & $?$ & $?$ & $?$ & $?$ \\
\hline H. maculata $\mathrm{KC} 122797$ & $?$ & $?$ & $?$ & $?$ & $?$ & $?$ & $?$ & $?$ & $?$ & $?$ & $?$ & $?$ & $?$ & $?$ & $?$ \\
\hline H. oblongispora JX993076 & 1 & 0 & 0 & 0 & 0 & 0 & 0 & 0 & 0 & 1 & 0 & 0 & 0 & 0 & 0 \\
\hline H. oblongispora JX993077 & 1 & 0 & 0 & 0 & 0 & 0 & 0 & 0 & 0 & 1 & 0 & 0 & 0 & 0 & 0 \\
\hline H. pallidula JX993078 & 1 & 0 & 1 & 0 & 1 & $?$ & $?$ & 1 & 0 & 0 & 0 & 0 & 0 & 0 & 0 \\
\hline H. robusta JX993079 & 1 & 0 & 1 & 1 & 0 & 1 & 1 & 1 & 0 & 0 & 1 & 0 & 1 & 1 & 0 \\
\hline H. solitaria KP860988 & 1 & 0 & 1 & 0 & 0 & 0 & 0 & 1 & 0 & 0 & 0 & 0 & 0 & 0 & 0 \\
\hline H. solitaria KР860989 & 1 & 0 & 1 & 0 & 0 & 0 & 0 & 1 & 0 & 0 & 0 & 0 & 0 & 0 & 0 \\
\hline H. solitaria AM397273 & $?$ & $?$ & $?$ & $?$ & $?$ & $?$ & $?$ & $?$ & $?$ & $?$ & $?$ & $?$ & $?$ & $?$ & $?$ \\
\hline H. stevensii JX993080 & 2 & 0 & 1 & 0 & 1 & $?$ & $?$ & 1 & 0 & 0 & 1 & 0 & 1 & 0 & 0 \\
\hline H. subglabra JX993081 & 2 & 0 & 0 & 0 & 1 & $?$ & $?$ & 0 & 1 & 0 & 1 & 0 & 1 & 0 & 0 \\
\hline H. aff. sulcata JX993082 & 2 & 1 & 0 & 1 & 0 & 0 & 1 & 0 & 0 & 0 & 0 & 0 & 0 & 0 & 0 \\
\hline
\end{tabular}




\begin{tabular}{|c|c|c|c|c|c|c|c|c|c|c|c|c|c|c|c|}
\hline & 1 & 2 & 3 & 4 & 5 & 6 & 7 & 8 & 9 & $\begin{array}{l}1 \\
0\end{array}$ & $\begin{array}{l}1 \\
1\end{array}$ & $\begin{array}{l}1 \\
2\end{array}$ & $\begin{array}{l}1 \\
3\end{array}$ & $\begin{array}{l}1 \\
4\end{array}$ & $\begin{array}{l}1 \\
5\end{array}$ \\
\hline H. aff. sulcata JX993083 & 2 & 1 & 0 & 1 & 0 & 0 & 1 & 0 & 1 & 0 & 1 & 0 & 0 & 0 & 0 \\
\hline H. aff. sulcata JX993084 & 2 & 1 & 0 & 1 & 0 & 0 & 1 & 0 & 1 & 0 & 0 & 0 & 0 & 0 & 0 \\
\hline H. ulvinenii JX993085 & 1 & 0 & 1 & 0 & 0 & 0 & 0 & 1 & 0 & 0 & 0 & 0 & 0 & 0 & 0 \\
\hline H. vespertina $\mathrm{KC} 122776$ & ? & $?$ & ? & ? & $?$ & $?$ & ? & $?$ & $?$ & ? & ? & ? & $?$ & ? & ? \\
\hline H. vespertina $\mathrm{KC} 122775$ & $?$ & $?$ & $?$ & $?$ & $?$ & $?$ & $?$ & $?$ & $?$ & $?$ & $?$ & $?$ & $?$ & $?$ & ? \\
\hline Peziza subclavipes JX993086 & 1 & 0 & 1 & 0 & 1 & $?$ & $?$ & 1 & 1 & 0 & 0 & 0 & 0 & 0 & 1 \\
\hline
\end{tabular}

\section{References}

Abbott, S. P., \& Currah, R. S. (1988). The genus Helvella in Alberta. Mycotaxon, 33, 229-250.

Abbott, S. P., \& Currah, R. S. (1997). The Helvellaceae: Systematic revision and occurrence in northern and northwestern North America. Mycotaxon, $62,1-125$.

Afzelius, A. (1783). Svamp-Slägtet Helvella. Kungliga Svenska Vetenskapsakademiens Handlingar, 4, 299-313.

Ainsworth, G. C., Sparrow, F. K., \& Sussman, A. S. (1973). The Fungi. An advanced treatise. IV A. A taxonomic review with keys: Ascomycetes and Fungi Imperfecti. New York: Academic Press.

Aljanabi, S. M., \& Martinez, I. (1997). Universal and rapid salt-extraction of high quality genomic DNA for PCR-based techniques. Nucleic Acids Research, 25, 4692-4693.

Alvarado, P., Moreno, G., Manjón, J. L., Gelpi, C., Kaounas, V., Konstantinidis, G., et al. (2011). Primeros datos moleculares de Delastria rosea, Fischerula macrospora e Hydnocystis piliger. Boletín de la Sociedad Micológica de Madrid, 35, 31-37.

Baral, H. O. (1987). Lugol's solution/IKI versus Melzer's reagent: Hemiamyloid. A universal feature of the ascus wall. Mycotaxon, 29, 399-450.

Bonito, G., Smith, M. E., Nowak, M., Healy, R. A., Guevara, G., Cázares, E., et al. (2013). Historical biogeography and diversification of truffles in the Tuberaceae and their newly identified southern hemisphere sister lineage. PLOS ONE, 8, 1-15.

Boudier, J. L. E. (1895). Description de quelques espèces récoltées en août 1894 dans les regions élevées des Alpes du Valais. Bulletin de la Société mycologique de France, 11, 27-30.

Breitenbach, J., \& Kränzlin, F. (1984). Fungi of Switzerland, Vol. I: Ascomycetes, Luzern: Verlag Mykologia.

Calonge, F. D. (2000). Validation or confirmation of some new taxa recently published. Boletín de la Sociedad Micológica de Madrid, 25, 301-302.

Calonge, F. D., \& Arroyo, I. (1990). Notes on the genus Helvella in Spain. Mycotaxon, 39, 203-217.

Dennis, R. W. G. (1981). British ascomycetes (3rd ed.). Vaduz: J. Cramer.

Dissing, H. (1966). The genus Helvella in Europe with special emphasis on the species found in Norden. Dansk Botanisk Arkiv, 25, 1-172.

Dissing, H. (1972). Specific and generic delimitation in Helvellaceae. Persoonia, $6,425-432$.

Dissing, H. (1979). Helvella papuensis, a new species from Papua New Guinea. Beihefte zur Sydowia, Annales Mycologici, Ser. II, 8, 156-161.

Dissing, H., Eckblad, F. E., \& Lange, M. (2000). Pezizales. Nordic Macromycetes, 1, 55-127.

Eckblad, F. (1968). The genera of the operculate Discomycetes. A re-evaluation of their taxonomy, phylogeny and nomenclature. Nytt Magasin for Botanikk, $15,1-191$.

Eernisse, D. J., \& Kluge, A. G. (1993). Taxonomic congruence versus total evidence, and amniote phylogeny inferred from fossils, molecules, and morphology. Molecular Biology and Evolution, 10, 1170-1195.

Felsenstein, J. (1985). Confidence limits on phylogenies: An approach using the bootstrap. Evolution, 39, 783-791.

Gamundi, I. J. (2010). Genera of Pezizales of Argentina 1. An updating of selected genera. Mycotaxon, 113, 1-60.

Häffner, J. (1987). Die gattung Helvella, morphologie und taxonomie. Beihefte zur Zeitschrift für Mykologie, 7, 1-165.
Hansen, K., \& Pfister, D. H. (2006). Systematics of the Pezizomycetes - The operculate discomycetes. Mycologia, 98, 1029-1040.

Hansen, H., Perry, B. A., Dranginis, A. W., \& Pfister, D. H. (2013). A phylogeny of the highly diverse cup-fungus family Pyronemataceae (Pezizomycetes, Ascomycota) clarifies relationships and evolution of selected life history traits. Molecular Phylogenetics and Evolution, 67, 311-335.

Harmaja, H. (1974). Notes on the genus Helvella, including the merging of the genus Wynnella. Karstenia, 14, 102-104.

Harmaja, H. (1977). A note on Helvella solitaria (syn. H. queletii) and H. confusa n. sp. Karstenia, 17, 40-44.

Harmaja, H. (1978). New species and combination in Helvella and Gyromitra. Karstenia, 18, 57.

Harmaja, H. (1979). Studies on cupulate species of Helvella. Karstenia, 19 , 33-45.

Harrington, F. A., Pfister, D. H., Potter, D., \& Donoghue, M. J. (1999). Phylogenetic studies within the Pezizales. I. 18S rRNA sequence data and classification. Mycologia, 91, 41-50.

Hobbie, E. A., Weber, N. S., \& Trappe, J. M. (2001). Mycorrhizal vs. saprotrophic status of fungi: The isotopic evidence. New Phytologist, 150, 601-610.

Index Fungorum (2015). www.speciesfungorum.org/Names/Names.asp Accessed 28.04.15.

Kaushal, S. C. (1991). Systematics of N. W. Hymalayan species of Helvella (operculate Discomycetes). In S. P. Khullar, \& M. P. Sharma (Eds.), Himalayan botanical researches (pp. 61-82). New Delhi: Ashish Publising House.

Kirk, P. M., Cannon, P. F., \& David, J. C. (Eds.). (2008). Ainsworth and Bisby's dictionary of the Fungi. Oxon: CABI Bioscience.

Korf, R. P. (1952). A monograph of the Arachnopezizeae. Lloydia, 14, 129-180, 1951

Korf, R. P. (1972). Synoptic key to the genera of the Pezizales. Mycologia, 64, 937-994.

Korf, R. P. (2008). Nomenclatural notes. 12. Untangling Hedwig's Octospora villosa: Helvella fibrosa comb. nov. Mycotaxon, 103, 307-312.

Læssøe, T., \& Hansen, K. (2007). Truffle trouble: What happened to the Tuberales? Mycological Research, 111, 1075-1099.

Landeros, F., \& Guzmán-Dávalos, L. (2013). Revisión del género Helvella (Ascomycota: Fungi) en México. Revista Mexicana de Biodiversidad (Supl. Micología), 84, S3-S20.

Landeros, F., Iturriaga, T., \& Guzmán-Dávalos, L. (2012). Type studies in Helvella (Pezizales) 1. Mycotaxon, 119, 35-63.

Landvik, S., Kristiansen, R., \& Schumacher, T. (1999). Pindara: A miniature Helvella. Mycologia, 91, 278-285.

Largent, D., Johnson, D., \& Watling, R. (1977). How to identify mushrooms to genus III: Microscopic features. Eureka: Mad River Press.

Leonard, L. M. (2006). Melzer's, lugol's or iodine for identification of whitespored Agaricales? McIlvainea, 16, 43-51.

Léveillé, J. H. (1841). Description de quelques espèces nouvelles des champignons. Annales des Sciences Naturelles, Botanique, 2e Série, 16 235-242.

Linnaeus, C. (1753). Species Plantarum. Holmiae.

Lundell, S., \& Nannfeldt, J. A. (1953). Fungi exsiccati suecici praesidium Upsaliensis, 41-42 (Nr. 2001-2100). pp. 1-52.

Maddison, D. R., \& Maddison, W. P. (2000). MacClade 4: Analysis of phylogeny and character evolution. Sunderland, MA: Sinauer Associates. 
Massee, G. (1895). British fungus-flora (vol. IV) London: George Bell \& Sons. Mycobank. (2015). http://www.mycobank.org/ Accessed 28.04.15.

Nannfeldt, J. A. (1937). Contribution to the mycoflora of Sweden. Svensk Botanisk Tidskrift, 31, 47-66,

Nguyen, N. H., Landeros, F., Garibay-Orijel, R., Hansen, K., \& Vellinga, E. C. (2013). The Helvella lacunosa species complex in western North America: cryptic species, misapplied names and parasites. Mycologia, 105, $1275-1286$

O’Donnell, K., Cigelnik, E., Weber, N. S., \& Trappe, J. M. (1997). Phylogenetic relationships among ascomycetous truffles and the true and false morels inferred from 18S y 28S ribosomal DNA sequence analysis. Mycologia, 89, 48-65.

Parslow, M., \& Spooner, B. (2009). Wynnella silvicola (Beck) Nannf. (Helvellaceae), an elusive British discomycete. Field Mycology, 10, 99-104.

Peck, C. H. (1902). New species of fungi. Bulletin of the Torrey Botanical Club, $29,69-74$

Posada, D., \& Crandall, K. A. (1998). Modeltest: Testing the model of DNA substitution. Bioinformatics, 14, 817-818.

Rifai, M. A. (1968). The Australasian Pezizales in the Herbarium of the Royal Botanical Gardens, Kew. Verhnaddelingen der Koninklijke Nedekandse Akademie Van Wetenschappen, Afd. Natuurkunde. Tweede Reeks, 57, $1-295$.

Ronquist, F., \& Huelsenbeck, J. P. (2003). MrBayes 3: Bayesian phylogenetic inference under mixed models. Bioinformatics, 19, 1572-1574.

Schaeffer, J. C. (1774). Fungorum qui in Bavaria et Palatinatu circa Ratisbonam nascuntur icones nativis coloribus expressae. Tome 3-4. Typis Henrici Godofredi Zunkelii: Ratisbonae.

Schumacher, T. (1992). New or noteworthy discomycetes. 2. Five new operculate discomycetes (Pezizales) from the Dovre Mountains, central south Norway. Mycotaxon, 63, 33-47.

Silvestro, D., \& Michalak, I. (2010). raxmlGUI: A graphical front-end for RAxML. http://sourceforge.net/projects/raxmlgui/. Accessed 12.06.12
Stamatakis, A. (2006). RAxML-VI-HPC: Maximum likelihood-based phylogenetic analyses with thousands of taxa and mixed models. Bioinformatics, 22, 2688-2690.

Swofford, D. L. (2002). PAUP: Phylogenetic analysis using parsimony (and other methods), version 4.0 b10. Sunderland, Massachusetts: Sinauer Associates.

Tedersoo, L., Hansen, K., Perry, B. A., \& Kjøller, R. (2006). Molecular and morphological diversity of pezizalean ectomycorrhiza. New Phytologist, 170, 581-596.

Thiers, B. (2012). Index Herbariorum: A global directory of public herbaria and associated staff (continuously updated). New York Botanical Garden's Virtual Herbarium. http://sweetgum.nybg.org/ih. Accessed 20.06.12

Van Vooren, N. (2010). Notes sur le genre Helvella L. (Ascomycota, Pezizales). 1. Le sous-genre Elasticae. Bulletin mycologique et botanique DauphinéSavoie, 199, 27-60

Vite-Garín, T., Villaruel-Ordaz, J. L., \& Cifuentes, J. (2006). Contribución al conocimiento del género Helvella (Ascomycota: Pezizales) en México: descripción de especies poco conocidas. Revista Mexicana de Biodiversidad, $77,143-151$.

Weber, N. S. (1972). The genus Helvella in Michigan. The Michigan Botanist, $11,147-201$.

Weber, N. S. (1975). Notes on western species of Helvella. I. Beihefte Nova Hedwigia, 51, 25-38.

White, T. J., Bruns, T. D., Lee, S., \& Taylor, J. (1990). Amplification and direct sequencing of fungal ribosomal RNA genes for phylogenetics. In M. A. Innis, D. H. Gelfand, J. J. Sninsky, \& T. J. White (Eds.), PCR protocols: A guide to methods and applications (10th ed., vol. IV, pp. 315-322). New York: Academic Press.

Wright, J. E., \& Albertó, E. (2006). Guía de los hongos de la región Pampeana II. Hongos sin laminillas. Buenos Aires: Literature of Latin America.

Zhuang, W. Y. (1995). Species diversity of Discomycetes in China. Chinese Biodiversity, 3, 43-48. 